\title{
Lactobacillus oeni sp. nov., from wine
}

\author{
Correspondence \\ Isabel Pardo \\ Isabel.Pardo@uv.es
}

\author{
Rosario Mañes-Lázaro, ${ }^{1}$ Sergi Ferrer, ${ }^{1}$ Ramón Rosselló-Mora ${ }^{2}$ \\ and Isabel Pardo ${ }^{1}$
}

1ENOLAB - Laboratorio de Microbiología Enológica, Departamento de Microbiología y Ecología, Facultad de Ciencias Biológicas, Universidad de Valencia, Dr Moliner 50, E-46100 Burjasot, Valencia, Spain

${ }^{2}$ Institut Mediterrani d'Estudis Avançats (CSIC-UIB), E-07190 Esporles, Mallorca, Spain
Ten Lactobacillus strains, previously isolated from different Bobal grape wines from the UtielRequena Origin Denomination of Spain, were characterized phylogenetically, genotypically and phenotypically. The 16S rRNA genes were sequenced and phylogenetic analysis showed that they form a tight phylogenetic clade that is closely related to reference strains Lactobacillus satsumensis NRIC 0604' ' 'Lactobacillus uvarum' 8 and Lactobacillus mali DSM 20444 ${ }^{\top}$. DNADNA hybridization results confirmed the separation of the strains from other Lactobacillus species. Genotypically, the strains could be differentiated from their closest neighbours by $16 \mathrm{~S}$ amplified rDNA restriction analysis and random amplified polymorphic DNA patterns. The strains were Gram-staining-positive, facultatively anaerobic rods that did not exhibit catalase activity. Phenotypically, they could be distinguished from their closest relatives by several traits such as their inabilities to grow at $\mathrm{pH} 3.3$, to ferment sucrose, amygdalin and arbutin or to hydrolyse aesculin. The characteristics of the ten wine isolates suggest that they represent a novel species, for which the name Lactobacillus oeni sp. nov. is proposed. The type strain is $59 b^{\top}$ ( $=$ CECT $7334^{\top}=$ DSM $19972^{\top}$ ).
Lactobacilli are Gram-positive, non-spore-forming, catalase-negative rods belonging to the group of lactic acid bacteria. They are found in a wide variety of habitats such as fermented beverages and foods, mucosal membranes and intestinal tracts of animals and humans, sewage and plant material (Bernardeau et al., 2008). Lactobacilli play an important role in the winemaking process because they can transform a large number of the compounds that are present in wine to the final products that determine a wine's organoleptic properties and, hence, its quality (Lafon-Lafourcade, 1983; Lafon-Lafourcade et al., 1983). Some Lactobacillus species are responsible for malolactic fermentation, although the species Oenococcus oeni is most frequently associated with this process. Malolactic fermentation is a desirable process in the production of quality wines because it reduces acidity, increases microbiological stability and improves organoleptic characteristics (Agouridis et al., 2005). Nevertheless, lactobacilli can also lead to detrimental effects as they can produce acetic

Abbreviations: ARDRA, amplified rDNA restriction analysis; RAPD, random amplified polymorphic DNA.

The GenBank/EMBL/DDBJ accession numbers for the $16 \mathrm{~S}$ rRNA gene sequences of strains $59 \mathrm{~b}^{\top}, 54,59 \mathrm{c}, 80,81,82,103,209 \mathrm{~g}, 376$ and 420 are AY681127 and EU821345-EU821353, respectively.

Phylogenetic trees based on 16S rRNA gene sequences and constructed using maximum-parsimony and neighbour-joining methods are available as supplementary figures with the online version of this paper. acid, off-flavours, ropiness and biogenic amines that can be toxic to humans (Fleet, 1993; Landete et al., 2005, 2007; Sponholz, 1993).

Because of the positive and negative effects of lactobacilli in wine, several studies have been done in recent years in order to investigate the diversity of Lactobacillus species that are associated with winemaking. As a consequence, some novel Lactobacillus species have been described (Rodas et al., 2006; Mañes-Lázaro et al., 2008a). Following a polyphasic study, Rodas et al. (2005) found a group of ten strains $\left(59 \mathrm{~b}^{\mathrm{T}}, 54,59 \mathrm{c}, 80,81,82,103,209 \mathrm{~g}\right.$, 376 and 420) that did not cluster with any of the known Lactobacillus species. The $16 \mathrm{~S}$ rRNA gene of strain $59 \mathrm{~b}^{\mathrm{T}}$ was sequenced and phylogenetic analysis showed that the closest reference strain was Lactobacillus mali DSM $20444^{\mathrm{T}}$, with $97.8 \%$ similarity.

The phylogenetic relationships of wine isolates and reference strains have been studied in depth, which include the latest descriptions of Lactobacillus satsumensis (Endo \& Okada, 2005), Lactobacillus vini (Rodas et al., 2006) and 'Lactobacillus uvarum' (Mañes-Lázaro et al., 2008b). There was some evidence to suggest that the ten strains characterized by Rodas et al. (2005) may represent a novel species. For this report, the ten strains and their nearest relatives were characterized phylogenetically, genotypically and phenotypically.

Strains were isolated by Rodas et al. (2005) from different Bobal wines produced in five different wineries from the 
Utiel-Requena Origin Denomination of Spain: strains $59 \mathrm{~b}^{\mathrm{T}}, 54$ and $59 \mathrm{c}$ from Sinarcas winery; strains 80,81 and 82 from Cuevas de Utiel winery; strain 103 from Fuenterrobles winery; 209g from Casas de Prada winery; and strains 376 and 420 from Requena winery. Reference strains L. mali DSM $20444^{\mathrm{T}}$, L. mali CECT 4149, L. mali CECT 7382, L. mali Lb44, L. mali Lb206, L. nagelii DSM $13675^{\mathrm{T}}$, L. satsumensis DSM $16230^{\mathrm{T}}$, L. satsumensis CECT 7371, L. satsumensis 4555 , 'L. uvarum' CECT 7335, ' $L$. uvarum' 24, 'L. uvarum' 68, L. vini CECT $5924^{\mathrm{T}}$, L. vini Lb154, L. vini Lb116 and the wine isolates were grown in MRS broth (Scharlab) supplemented with $0.5 \mathrm{~g}$ L-cysteine hydrochloride $\mathrm{l}^{-1}$ (mMRS) under the conditions described by Rodas et al. (2003).

Sequences of the 16S rRNA genes from strains $59 \mathrm{~b}^{\mathrm{T}}, 54$, $59 \mathrm{c}, 80,81,82,103,209 \mathrm{~g}, 376$ and 420 were obtained in this work by applying the methods described by Rodas et al. (2005). Although the 16S rRNA sequence of strain $59 \mathrm{~b}^{\mathrm{T}}$ was already available in GenBank, we sequenced this gene again and the deposited sequence has been updated. Almost-complete 16S rRNA gene sequences from the wine isolates and their nearest relatives were subjected to phylogenetic analysis. Neighbour-joining with Kimura's two-parameter model of nucleotide substitution, maximum-parsimony and maximum-likelihood methods were applied in the BioNumerics version 2.5 software package to infer the phylogeny of those strains. Fig. 1 shows the tree that was constructed using maximum likelihood. The

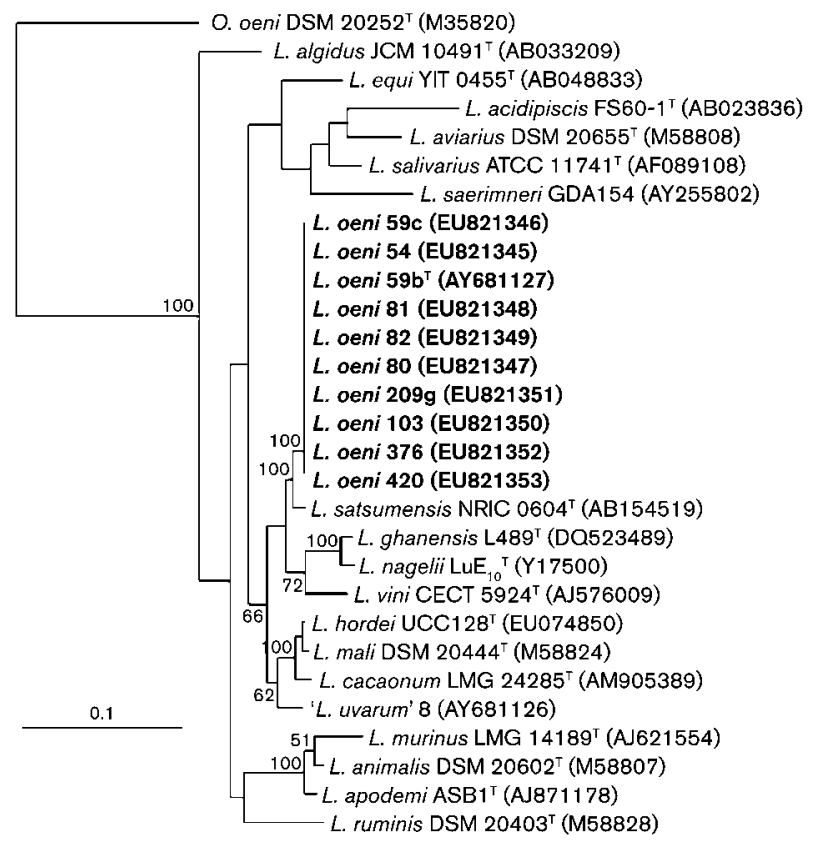

Fig. 1. Phylogenetic tree based on $16 \mathrm{~S}$ rRNA gene sequences and constructed using the maximum-likelihood method. Bootstrap values $(\geqslant 50 \%)$ based on 1000 resamplings are shown at branch nodes. Oenococcus oeni DSM $20252^{\top}$ was used as the outgroup. Bar, $10 \%$ nucleotide sequence divergence. topology of the branches was the same when maximum parsimony was applied and slightly different when neighbour joining was applied (see Supplementary Figs S1 and S2, available in IJSEM Online). The similarity of the $16 \mathrm{~S}$ rRNA gene sequences between the ten wine isolates was at least $99.83 \%$. The $16 \mathrm{~S}$ rRNA gene of strain $59 \mathrm{~b}^{\mathrm{T}}$ showed $99.1 \%$ sequence similarity with L. satsumensis NRIC $0604^{\mathrm{T}}$, $97.5 \%$ with ' $L$. uvarum' 8 (=CECT 7335 ), $97.2 \%$ with $L$. mali DSM $20444^{\mathrm{T}}$ and $L$. hordei UCC $128^{\mathrm{T}}, 96.6 \%$ with $L$. cacaonum LMG $24285^{\mathrm{T}}, 96.5 \%$ with L. ghanensis $\mathrm{L} 489^{\mathrm{T}}$ and $96.2 \%$ with $L$. vini CECT $5924^{\mathrm{T}}$ and L. nagelii $\mathrm{LuE}_{10}{ }^{\mathrm{T}}$. All of these species belong to the L. salivarius phylogenetic group (Felis \& Dellaglio, 2007).

DNA-DNA hybridization experiments were performed as described by Urdiain et al. (2008) to ascertain whether the wine strains represented a novel species. DNA-DNA hybridization was first performed between strains $59 \mathrm{~b}^{\mathrm{T}}$ and 54. The result, expressed as a mean percentage value based on two independent hybridization experiments, was $100 \%$, which indicates that these two strains belong to the same species. Hybridizations between strain $59 \mathrm{~b}^{\mathrm{T}}$ and $L$. mali DSM 20444 ${ }^{\mathrm{T}}$, L. mali CECT 7382, L. nagelii CECT $5983^{\mathrm{T}}$, 'L. uvarum' CECT 7335 and L. vini CECT $5924^{\mathrm{T}}$ produced mean results of $30.7,38.3,32.1,35.5$ and $34.2 \%$, respectively. Finally, two reciprocal hybridization experiments using genomic DNA from strains L. satsumensis CECT 7371 and L. mali CECT 7382 as templates against strain $59 \mathrm{~b}^{\mathrm{T}}$ resulted in mean values of 47.6 and $55.1 \%$, respectively. All of these values are below $70 \%$, which confirms that $59 \mathrm{~b}^{\mathrm{T}}$ is a member of a novel species (Stackebrandt \& Goebel, 1994).

16S amplified rDNA restriction analysis (ARDRA) and random amplified polymorphic DNA (RAPD) analysis were applied to characterize these strains genotypically. Restriction of the amplified 16S rRNA genes with BfaI distinguished the wine isolates from L. nagelii CECT $5983^{\mathrm{T}}$ and $L$. vini strains but not from L. mali, L. satsumensis or 'L. uvarum' strains, whereas restriction with MseI distinguished the wine isolates from all of the other strains used. These results confirm the higher discriminatory power of Msel compared with $B f a I$ that was noted by Rodas et al. (2003). RAPD analysis with primers COC and 17R differentiated the wine isolates from strains belonging to other species, forming a cluster of the ten isolates with 78.53 and $77.25 \%$ similarity, respectively. As shown in the dendrogram derived from the combined analysis (Fig. 2), the wine isolates formed a tight cluster with $89.87 \%$ similarity. COC fingerprinting was useful to discriminate all of the $L$. vini, 'L. uvarum', $L$. mali and $L$. satsumensis strains, but only some of the wine isolates. RAPD with primer 17R had less discriminatory power than COC at the strain level.

The $\mathrm{G}+\mathrm{C}$ content of strain $59 \mathrm{~b}^{\mathrm{T}}$ was determined by hydrolysing the DNA enzymically and quantifying the nucleosides by HPLC as described by Tamaoka \& Komagata (1984) and Ziemke et al. (1998). The G+C 


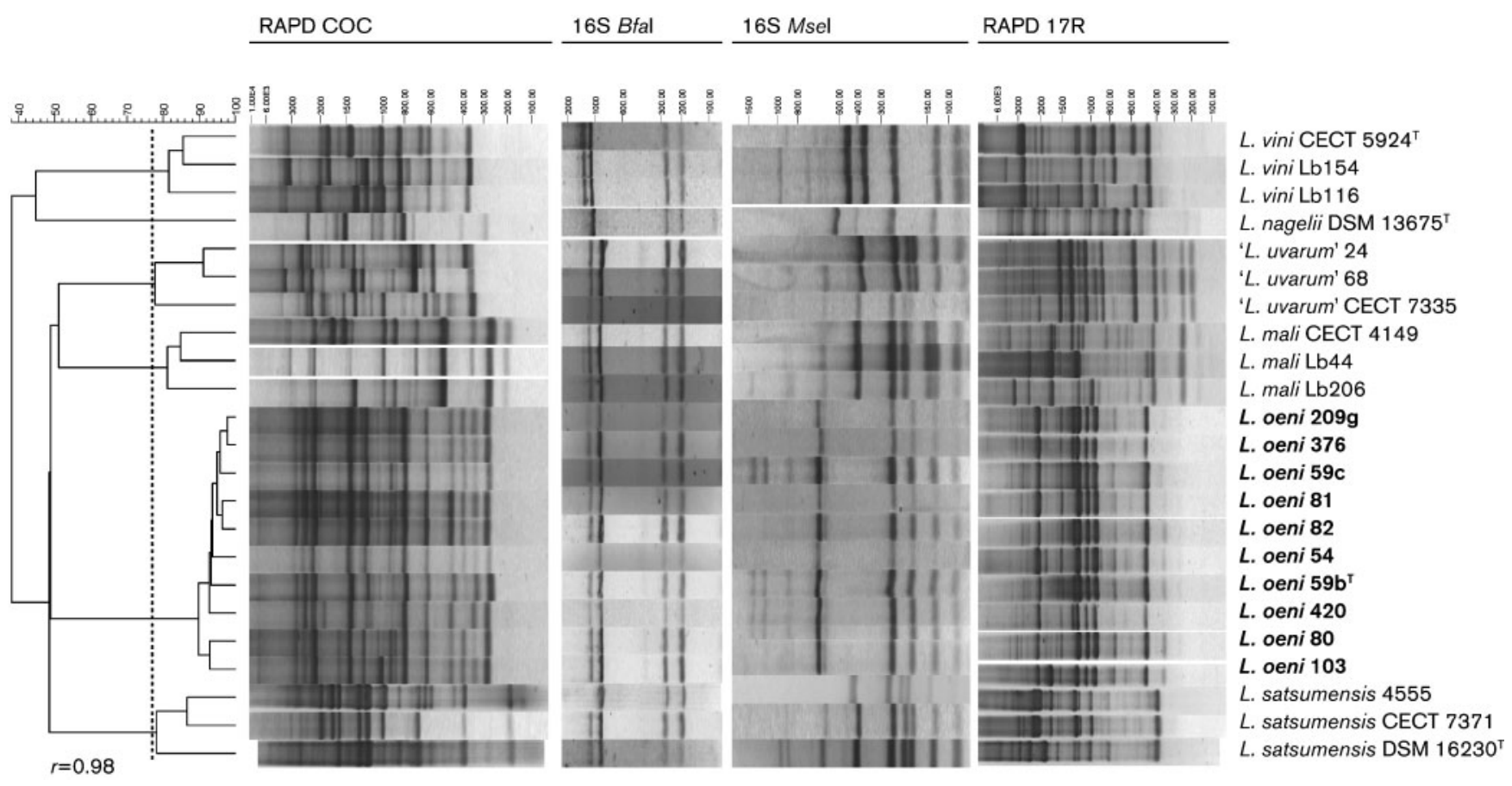

Fig. 2. Dendrogram derived from comparison of the combined RAPD (COC and 17R) and 16S ARDRA (Msel and Bfal) patterns obtained from strains $59 b^{\top}, 54,59 c, 80,81,82,103,209 \mathrm{~g}, 376$ and 420 and reference strains. Levels of similarity between the patterns were calculated by using similarity coefficients from each technique and the clustering is based on the UPGMA method. The vertical dotted line indicates the $78 \%$ similarity value for delineating clusters. The calculated global cophenetic correlation value for the global analysis was 98 .

content is $37.17 \pm 0.16 \mathrm{~mol} \%$, a value that is within the range (32-53 mol\%) established for the genus Lactobacillus and similar to the $\mathrm{G}+\mathrm{C}$ contents of $L$. mali and $L$. satsumensis, 32-34 and 39-41 mol\%, respectively.

To test for the presence of D-meso-diaminopimelic acid in strain $59 \mathrm{~b}^{\mathrm{T}}$, whole cells were hydrolysed with $4 \mathrm{M} \mathrm{HCl}$ at $100{ }^{\circ} \mathrm{C}$ for $15 \mathrm{~h}$ and the hydrolysates were subjected to thin-layer chromatography on cellulose plates using the solvent system of Rhuland et al. (1955). D-mesoDiaminopimelic acid was detected in strain $59 \mathrm{~b}^{\mathrm{T}}$; similarly, it has been detected in L. mali (http://www.dsmz.de) and $L$. satsumensis (Endo \& Okada, 2005; Felis \& Dellaglio, 2007).

The phenotypic traits of the wine isolates are given in Table 1 and the species description. Strains $59 \mathrm{~b}^{\mathrm{T}}, 54,59 \mathrm{c}, 80,81$, $82,103,209 \mathrm{~g}, 376$ and 420 are Gram-positive, catalasenegative and microaerophilic lactobacilli. They form Llactate from glucose and do not ferment gluconate or ribose: thus, they are considered as homofermentative. Colonies measure $0.8-1.2 \mathrm{~mm}$ in diameter and are white, smooth, circular and regular when grown on mMRS agar at $28{ }^{\circ} \mathrm{C}$ for 4 days. Cells are rods, $0.63-0.92 \mu \mathrm{m}$ wide and $1.38-3.41 \mu \mathrm{m}$ long (mean size $0.80 \times 2.36 \mu \mathrm{m}$ ). Cells are motile (except strain 376) and non-spore-forming and occur mainly in pairs but also in short chains of up to five cells. All strains grow at $15,25,37$ and $45{ }^{\circ} \mathrm{C}$ but not at $5{ }^{\circ} \mathrm{C}$. They grow at $\mathrm{pH} 4.5$ and 8.0 , but not at $\mathrm{pH} 3.3$, and with $5 \%(\mathrm{w} / \mathrm{v}) \mathrm{NaCl}$ (except strain 80$)$ and $10 \%(\mathrm{v} / \mathrm{v})$ ethanol, but not with $10 \%(\mathrm{w} / \mathrm{v}) \mathrm{NaCl}$. They produce exopolysaccharide from sucrose but do not produce ammonia from arginine or mannitol from fructose. They are able to transform L-malic acid into L-lactic acid in MRS broth supplemented with $5 \mathrm{~g}$ malic acid $\mathrm{l}^{-1}$. This characteristic, as well as the ability to grow with $10 \%$ ethanol, is seen in other species that have been isolated from wine (Henick-Kling, 1993; Pardo \& Zúñiga, 1992).

The abilities of the wine isolates and the reference strains to ferment carbohydrates were tested with the API $50 \mathrm{CH}$ system (bioMérieux) according to the manufacturer's instructions. All of the wine isolates ferment $\mathrm{N}$-acetylglucosamine, fructose, glucose, methyl $\alpha$-D-glucoside, mannitol, mannose, sorbitol, L-sorbose and trehalose. They do not ferment D-adonitol, amygdalin, D- or L-arabinose, Dor L-arabitol, arbutin, cellobiose, dulcitol, erythritol, D- or L-fucose, galactose, gluconate, 2- or 5-ketogluconate, glycogen, inositol, inulin, lactose, D-lyxose, maltose, melezitose, melibiose, raffinose, rhamnose, D-ribose, starch, sucrose, D-tagatose, turanose, xylitol, D- or L-xylose, methyl $\alpha$-D-mannoside or methyl $\beta$-xyloside and do not hydrolyse aesculin. Strains 54, 81, 80 and 376 ferment glycerol weakly but the other strains do not. Strain 103 ferments salicin and $\beta$-gentiobiose but the other strains do not. 
Table 1. Differential traits between Lactobacillus oeni sp. nov. strains and their closest phylogenetic neighbours

Reference strains: 1, L. mali CECT 4149 (data from Rodas et al., 2006); 2, L. satsumensis DSM 16230 (Rodas et al., 2006); 3, 'L. uvarum' CECT 7335 (Mañes-Lázaro et al., 2008b). All strains produce L-lactic acid isomer. All strains are positive for growth at $\mathrm{pH} 4.5$ and 8.0 , fermentation of $\mathrm{N}$ acetylglucosamine, D-fructose, D-glucose, D-mannitol, D-mannose and trehalose and production of exopolysaccharide from sucrose. All strains are negative for growth with $10 \% \mathrm{NaCl}$, production of ammonia from arginine and mannitol from fructose and fermentation of D-adonitol, D- and Larabinose, D- and L-arabitol, dulcitol, erythritol, D- and L-fucose, gluconate, 2- and 5-ketogluconate, glycogen, inositol, inulin, lactose, D-lyxose, melezitose, melibiose, raffinose, D-ribose, starch, D- and L-xylose, xylitol and methyl $\beta$-D-xyloside. + , Positive; - , negative; $\mathrm{W}$, weak; ND, no data available.

\begin{tabular}{|c|c|c|c|c|c|c|c|c|c|c|c|c|c|}
\hline \multirow[t]{2}{*}{ Characteristic } & \multicolumn{10}{|c|}{ Lactobacillus oeni sp. nov. } & \multirow[t]{2}{*}{1} & \multirow[t]{2}{*}{2} & \multirow[t]{2}{*}{3} \\
\hline & $59 b^{T}$ & 54 & $59 \mathrm{c}$ & 80 & 81 & 82 & 103 & $209 \mathrm{~g}$ & 376 & 420 & & & \\
\hline \multicolumn{14}{|l|}{ Growth at/with: } \\
\hline pH 3.3 & - & - & - & - & - & - & - & - & - & - & + & + & - \\
\hline $5 \% \mathrm{NaCl}$ & + & + & + & - & + & + & + & + & + & + & - & + & + \\
\hline \multicolumn{14}{|l|}{ Fermentation of: } \\
\hline Aesculin ferric citrate & - & - & - & - & - & - & - & - & - & - & + & + & + \\
\hline Amygdalin & - & - & - & - & - & - & - & - & - & - & + & + & + \\
\hline Arbutin & - & - & - & - & - & - & - & - & - & - & + & + & + \\
\hline Cellobiose & - & - & - & - & - & - & - & - & - & - & + & - & - \\
\hline Maltose & - & - & - & - & - & - & - & - & - & - & - & + & + \\
\hline Methyl $\alpha$-D-mannoside & - & - & - & - & - & - & - & - & - & - & - & + & - \\
\hline L-Rhamnose & - & - & - & - & - & - & - & - & - & - & - & + & - \\
\hline Salicin & - & - & - & - & - & - & + & - & - & - & - & + & + \\
\hline D-Sorbitol & + & + & + & + & + & + & + & + & + & + & + & + & - \\
\hline L-Sorbose & + & + & + & + & + & + & + & + & + & + & - & + & - \\
\hline Sucrose & - & - & - & - & - & - & - & - & - & - & + & + & + \\
\hline D-Tagatose & - & - & - & - & - & - & - & - & - & - & - & + & - \\
\hline Turanose & - & - & - & - & - & - & - & - & - & - & - & + & + \\
\hline
\end{tabular}

All of these analyses confirm that status should be given to the wine isolates $59 \mathrm{~b}^{\mathrm{T}}, 54,59 \mathrm{c}, 80,81,82,103,209 \mathrm{~g}, 376$ and 420 at the species level and, therefore, the novel species Lactobacillus oeni sp. nov. is proposed.

\section{Description of Lactobacillus oeni sp. nov.}

Lactobacillus oeni (oe' ni. N.L. gen. n. oeni of wine).

Gram-positive, non-spore-forming rods, $0.63-0.92 \mu \mathrm{m}$ wide by $1.38-3.41 \mu \mathrm{m}$ long. Nine of ten known strains are motile. Cells are found singly, in pairs and in short chains. Microaerophilic. Colonies on MRS agar after 4 days of incubation at $28{ }^{\circ} \mathrm{C}$ are $0.8-1.2 \mathrm{~mm}$ in diameter, smooth, circular, regular and white. Catalase-negative. Growth occurs at $15-45{ }^{\circ} \mathrm{C}$ but not at $5{ }^{\circ} \mathrm{C}$, at $\mathrm{pH} 4.5-8.0$ but not at pH 3.3 and with $10 \%$ ethanol. Transforms Lmalic acid into L-lactic acid. Homofermentative: does not ferment gluconate or ribose. L-Lactate is produced as the end product from hexoses. Ammonia is not produced from arginine and mannitol is not produced from fructose.
Exopolysaccharide is produced from sucrose. Acid is produced from $\mathrm{N}$-acetylglucosamine, fructose, glucose, mannose, mannitol, sorbitol, L-sorbose, methyl $\alpha$-Dglucoside and trehalose but not from adonitol, amygdalin, D- or L-arabinose, D- or L-arabitol, arbutin, cellobiose, dulcitol, erythritol, D- or L-fucose, galactose, gluconate, 2or 5-ketogluconate, glycogen, inositol, inulin, D-lyxose, lactose, maltose, melezitose, melibiose, raffinose, rhamnose, ribose, starch, sucrose, D-tagatose, turanose, xylitol, D- or L-xylose, methyl $\alpha$-D-mannoside or methyl $\beta$ xyloside. Aesculin is not hydrolysed. Acid production from glycerol is strain dependent. Nine of ten known strains ferment salicin and $\beta$-gentiobiose. The cell wall contains peptidoglycan of the D-meso-diaminopimelic acid type. The DNA $\mathrm{G}+\mathrm{C}$ content of the type strain is $37.17 \pm 0.16 \mathrm{~mol} \%$.

The type strain is $59 \mathrm{~b}^{\mathrm{T}}\left(=\right.$ CECT $7334^{\mathrm{T}}=$ DSM $\left.19972^{\mathrm{T}}\right)$. The type strain and additional strains of the species, 54, 59c, 80, 81, 82, 103, 209g, 376 and 420, were isolated in 1997 by A. M. Rodas from Bobal wine. 


\section{Acknowledgements}

This work has been partially supported by CYCYT ALI97-1077-C0201 and RM2007-00007-00-00. We wish to thank Mercedes Urdiain for kindly helping with the hybridization and $\mathrm{G}+\mathrm{C}$ analysis. R. R.-M. acknowledges the financial support of the project CLG2006-12714C02-02 of the Spanish Ministry of Science and Education.

\section{References}

Agouridis, N., Bekatorou, A., Nigam, P. \& Kanellaki, M. (2005). Malolactic fermentation in wine with Lactobacillus casei cells immobilized on delignified cellulosic material. J Agric Food Chem 53, 2546-2551.

Bernardeau, M., Vernoux, J. P., Henri-Dubernet, S. \& Guéguen, M. (2008). Safety assessment of dairy microorganisms: the Lactobacillus genus. Int J Food Microbiol 126, 278-285.

Endo, A. \& Okada, S. (2005). Lactobacillus satsumensis sp. nov., isolated from mashes of shochu, a traditional Japanese distilled spirit made from fermented rice and other starchy materials. Int J Syst Evol Microbiol 55, 83-85.

Felis, G. E. \& Dellaglio, F. (2007). Taxonomy of lactobacilli and bifidobacteria. Curr Issues Intest Microbiol 8, 44-61.

Fleet, G. H. (1993). The microorganisms of winemaking - isolation, enumeration and identification. In Wine: Microbiology and Biotechnology, pp. 1-25. Edited by G. H. Fleet. Chur: Hardwood Academic.

Henick-Kling, T. (1993). Malolactic fermentation. In Wine: Microbiology and Biotechnology, pp. 289-326. Edited by G. H. Fleet. Chur: Hardwood Academic.

Lafon-Lafourcade, S. (1983). Wine and brandy. In Biotechnology, vol. 5, pp. 81-163. Edited by G. Reed. Basel: Verlag Chemie.

Lafon-Lafourcade, S., Carre, E. \& Ribéreau-Gayon, P. (1983). Occurrence of lactic acid bacteria during different stages of vinification and conservation of wines. Appl Environ Microbiol 46, 874-880.

Landete, J. M., Ferrer, S. \& Pardo, I. (2005). Which lactic acid bacteria are responsible for histamine production in wine? J Appl Microbiol 99, 580-586.

Landete, J. M., Pardo, I. \& Ferrer, S. (2007). Tyramine and phenylethylamine production among lactic acid bacteria isolated from wine. Int J Food Microbiol 115, 364-368.
Mañes-Lázaro, R., Ferrer, S., Rodas, A. M., Urdiain, M. \& Pardo, I. (2008a). Lactobacillus bobalius sp. nov., a new lactic acid bacterium isolated from Spanish Bobal grape must. Int J Syst Evol Microbiol 58, 2699-2703.

Mañes-Lázaro, R., Ferrer, S., Rosselló-Mora, R. \& Pardo, I. (2008b). Lactobacillus uvarum sp. nov., a new lactic acid bacterium isolated from Spanish Bobal grape must. Syst Appl Microbiol 31, 425-433.

Pardo, I. \& Zúñiga, M. (1992). Lactic acid bacteria in Spanish red rosé and white musts and wines under cellar conditions. J Food Sci 57, 392-395.

Rhuland, L. E., Work, E., Denman, R. F. \& Hoare, D. S. (1955). The behavior of the isomers of $\alpha, \varepsilon$-diaminopimelic acid on paper chromatograms. J Am Chem Soc 77, 4844-4846.

Rodas, A. M., Ferrer, S. \& Pardo, I. (2003). 16S-ARDRA, a tool for identification of lactic acid bacteria isolated from grape must and wine. Syst Appl Microbiol 26, 412-422.

Rodas, A. M., Ferrer, S. \& Pardo, I. (2005). Polyphasic study of wine Lactobacillus strains: taxonomic implications. Int J Syst Evol Microbiol 55, 197-207.

Rodas, A. M., Chenoll, E., Macián, M. C., Ferrer, S., Pardo, I. \& Aznar, R. (2006). Lactobacillus vini sp. nov., a wine lactic acid bacterium homofermentative for pentoses. Int J Syst Evol Microbiol 56, 513-517.

Sponholz, W. R. (1993). Wine spoilage by microorganisms. In Wine: Microbiology and Biotechnology, pp. 395-420. Edited by G. H. Fleet. Chur: Hardwood Academic Publishers.

Stackebrandt, E. \& Goebel, B. M. (1994). Taxonomic note: a place for DNA-DNA reassociation and $16 \mathrm{~S}$ rRNA sequence analysis in the present species definition in bacteriology. Int J Syst Bacteriol 44, 846849.

Tamaoka, J. \& Komagata, K. (1984). Determination of DNA base composition by reversed-phase high-performance liquid chromatography. FEMS Microbiol Lett 25, 125-128.

Urdiain, M., López-López, A., Gonzalo, C., Busse, H.-J., Langer, S., Kämpfer, P. \& Rosselló-Mora, R. (2008). Reclassification of Rhodobium marinum and Rhodobium pfennigii as Afifella marina gen. nov. comb. nov. and Afifella pfennigii comb. nov., a new genus of photoheterotrophic Alphaproteobacteria and emended descriptions of Rhodobium, Rhodobium orientis and Rhodobium gokarnense. Syst Appl Microbiol 31, 339-351.

Ziemke, F., Höfle, M. G., Lalucat, J. \& Rosselló-Mora, R. (1998). Reclassification of Shewanella putrefaciens Owen's genomic group II as Shewanella baltica sp. nov. Int J Syst Bacteriol 48, 179-186. 